\title{
Composition of Anastrepha species (Diptera: Tephritidae) in habitats with different levels of anthropogenic activity
}

\author{
Monique Barbara Rosa Oliveira ${ }^{1 *}$ \\ Elisângela Novais Lopes Ferreira ${ }^{1}$ \\ Carolina Reigada ${ }^{1}$ \\ Gleidyane Novais Lopes ${ }^{1}$ \\ Leandro José Uchôa Lemos ${ }^{1}$ \\ Keiko Uramoto ${ }^{1}$ \\ Miguel Francisco Souza-Filho ${ }^{2}$ \\ Roberto Antonio Zucchi ${ }^{1}$ \\ ${ }^{1}$ Departamento de Entomologia e Acarologia, Escola Superior de Agricultura "Luiz de Queiroz" \\ Avenida Pádua Dias, 11, CEP 13418-900, Piracicaba - SP, Brasil \\ ${ }^{2}$ Instituto Biológico, Agência Paulista de Tecnologia dos Agronegócios - APTA \\ Secretaria de Agricultura e Abastecimento, Campinas - São Paulo, Brasil \\ * Autor para correspondência \\ oliveira.mbr@hotmail.com
}

Submetido em 16/11/2016

Aceito para publicação em 08/06/2017

\section{Resumo}

Composição das espécies de Anastrepha (Diptera: Tephritidae) em habitats com diferentes níveis de atividade antropogênica. Coletamos espécies de Anastrepha em três áreas (ambiente urbano, estação de pesquisa e agricultura) e comparamos as comunidades por índices faunísticos (dominância, abundância, frequência e constância). A diversidade de espécies foi estimada usando a estatística $Q$ e calculando os índices Shannon, Margalef Pielou e Berger-Parker. A semelhança entre as áreas foi baseada nos coeficientes de Sørensen e Bray-Curtis. As áreas do ambiente urbano e da estação de pesquisa apresentaram maior diversidade e similaridade de espécies de Anastrepha. A composição das espécies diferiu entre as áreas, com predominância de $A$. fraterculus (Wiedemann, 1830) nas três áreas. Os padrões de distribuição não diferiram depois de ajustar as séries geométricas. A área agrícola era a mais diversificada e mais parecida com a área urbana em termos de abundância. A área urbana e a estação de pesquisa eram as mais diversas e eram semelhantes em composição de espécies de Anastrepha. Apesar de estarem sujeitos a diferentes níveis de perturbação humana, esses resultados sugerem que o padrão de abundância e distribuição de espécies de Anastrepha é semelhante nas três áreas.

Palavras-chave: Abundância; Diversidades alfa e beta; Moscas-das-frutas; Similaridade 


\section{Abstract}

We collected Anastrepha species in three areas (urban, research station, agricultural) and compared communities by faunal indices (dominance, abundance, frequency, and constancy). Species diversity was estimated using the Q-statistic and by calculating Shannon, Margalef Pielou and Berger-Parker indices. Similarity among areas was based on Sørensen and Bray-Curtis coefficients. The urban and research station areas presented greater diversity and similarity of Anastrepha species. Species composition differed between areas, with predominance of $A$. fraterculus (Wiedemann, 1830) in the three areas. Distribution patterns did not differ after adjusting the geometric series. The agricultural area was the least diverse and more closely resembled the urban area in terms of abundance. The urban area and research station were the most diverse, and were similar in composition of Anastrepha species. Despite being subject to different levels of human disturbance, these results suggest that the abundance and distribution pattern of Anastrepha species are similar in all three areas.

Key words: Abundance; Alpha and beta diversities; Fruit flies, Similarity

\section{Introduction}

Several species of fruit flies have strong economic importance worldwide. The genus Anastrepha is the most diverse of the Tephritid flies in tropical and subtropical environments (NORRBOM et al., 2012), and the greatest diversity of Anastrepha species occurs in Brazil (ZUCCHI, 2008). Studies of species composition can generate information about fruit fly strategies for exploitation of resources in croplands and adjacent areas. This knowledge helps to predict outbreaks of pests, to establish control alternatives, and to reduce losses caused by pest species (BERRYMAN, 1986). Studies of species distribution patterns are then key to understanding the importance of this insect group in agroecosystems (GOTELLI, 2009).

Population studies of these taxa are crucial for understanding population dynamics, and to facilitate comparisons among communities. Each biological community possesses unique interconnections, and this characteristic facilitates characterization and separation from other communities through indices that express species diversity (SILVEIRA NETO et al., 1976). The dominance level of fruit fly species seems to be related to various ecological components, of which abundance, diversity, and richness are the most relevant (CELEDONIO-HURTADO et al., 1995). We studied the Anastrepha species community in three areas (urban, research station, and agricultural) with different anthropogenic disturbance, based on abundance, diversity (alpha and beta), and associations of species with each area. We then evaluated whether habitat type influences Anastrepha species composition in the community.

\section{Material and Methods}

We analyzed records of fruit fly occurrence from previous surveys (URAMOTO et al., 2003; LEMOS et al., 2015; LOPES et al., 2015) for three study locations in the state of São Paulo, Brazil, with different degrees of anthropogenic disturbance. Each area was characterized as follows: (1) an urban area in the city of Piracicaba, University of São Paulo "Luiz de Queiroz" Campus, (2242'30”'S 47³8'00”W), with $546 \mathrm{~m}$ altitude, an area of 914.5 ha, composed of buildings, native forest remnants, experimental crops, and several species of fruit trees without pesticide treatments (July 1998 to June 1999) (URAMOTO et al., 2003); (2) a research station in Monte Alegre do Sul (22 41'42"S; $46^{\circ} 40$ '22"W) with an altitude of $760 \mathrm{~m}$, an area of 0.92 ha, composed of guava, peach and loquat and adjacent native forest, and lacking phytosanitary treatment and without fruit harvest (January to December 2002) (LOPES et al., 2015); (3) an agricultural area in Monte Alto (2113'27.1's; 48³6'9.2”'W) with $588 \mathrm{~m}$ altitude, an area of 3.75 ha, composed of a commercial guava orchard, plums, and with phytosanitary treatment, in which fruits harvested regularly (January to December 2004) (LEMOS et al., 2015). The average temperature in these municipalities varied over the study period from 20.8 to $22.8^{\circ} \mathrm{C}$, and annual precipitation ranged from 1,440 to $1,522 \mathrm{~mm}$. 
We placed six traps approximately $25 \mathrm{~m}$ apart in trees baited with hydrolyzed corn protein (urban and agricultural areas) and torula yeast (research station), which were replaced weekly. Species identification of collected specimens was based on females (ZUCCHI, 2000). The samples were deposited in the Center for Nuclear Energy in Agriculture (CENA/USP) in Piracicaba, and Experimental Center of the Biological Institute in Campinas, São Paulo. Species were classified into faunal categories (SILVEIRA NETO et al., 2014), and rarefaction curves were adjusted to describe the sampling effort in each area. The Q-statistic was calculated based on species abundance distributions. Species accumulation curves were generated, and the interquartile range was used to measure diversity; this region of the curve was chosen because at that point neither rare nor abundant species influence the results (MAGURRAN, 2004). Diversity was assessed using Margalef $\left(\mathrm{D}_{M g}\right)$ (richness), Pielou ( $\left.J^{\prime}\right)$ (equitability), Berger-Parker (d) (dominance) and Shannon $\left(H^{\prime}\right)$ (diversity) indices (MAGURRAN, 2004). We used the Chao 2 estimator to calculate expected richness for each area separately.

Associations among the species and areas were defined using a heat map graph Euclidean distances. Color variation on the map (yellow, green, and red) indicates the strength of interactions between each species and the area (red = higher degree of association; yellow $=$ lower degree). Beta diversity (similarity among areas) was calculated using the Sørensen coefficient (Cs), and Bray-Curtis indices were used to compare species composition and abundance among areas. The analyses were performed using Anafau software (SILVEIRA NETO et al., 2014), PAST 1.73 (Paleontological Statistics) (HAMMER et al., 2007) and R version 3.0.1 (R CORE TEAM, 2013).

\section{Results}

We collected a total of 49,583 specimens across all areas belonging to 22 species. We captured 26,296 specimens $(53.03 \%)(\mathrm{S}=18)$ in the research station, 12,201 specimens $(24.61 \%)(\mathrm{S}=17)$ in the urban area, and 11,086 specimens $(22.36 \%)(\mathrm{S}=8)$ in the agricultural area (Table 1). Species composition differed among areas, and only five species were found in all three areas [Anastrepha fraterculus (Wiedemann, 1830), A. pickeli Lima, 1934, A. pseudoparallela (Loew, 1873), A. sororcula Zucchi, 1979 and A. zenildae Zucchi, 1979]. The least common species were A. pickeli and A. zenildae (Table 1). Some species occurred only in one area (Table 1), and less than 40 specimens were collected for most species. Anastrepha fraterculus was the most abundant in all three areas with over $80 \%$ relative abundance, and was the species with the largest faunal indices (dominance, abundance, frequency, and constancy). Anastrepha bistrigata Bezzi, 1919 and A. obliqua (Marquart, 1835) were prevalent in the urban area and research station, $A$. sororcula was found in both agricultural and research station, and $A$. pseudoparallela was found only in the urban area (Table 1).

The rarefaction curve achieved stabilization (asymptote) in all three areas, indicating that species diversity among areas was appropriately sampled (Figure 1). The highest diversity values were in the research station $(\mathrm{Q}=2.84)$ and the urban area $(\mathrm{Q}=$ $2.50)$, followed by the agricultural area $(Q=0.81)$. Five species (cumulative number) were classified as 'rare' in the research station, three in the urban area, and none in the agricultural area (Figure 2; Table 1).

Shannon diversity did not differ $(\mathrm{p}>0.05)$ between the urban area $\left(H^{\prime}=2.03\right)$ and the research station $\left(H^{\prime}=\right.$ 1,965). These two areas had the highest species richness (Margalef index). Diversity and richness were lower in the agricultural area (Table 2). Estimated richness was similar to observed richness. Equitability and dominance values were high in all three areas (nearly 1) (Table 2). 
TABLE 1: List of Anastrepha species in three different environments in the state of São Paulo, Brazil.

\begin{tabular}{|c|c|c|c|c|c|c|c|c|c|c|c|c|}
\hline \multirow{3}{*}{ Species } & \multicolumn{12}{|c|}{ Area } \\
\hline & \multicolumn{4}{|c|}{ Urban } & \multicolumn{4}{|c|}{ Research station } & \multicolumn{4}{|c|}{ Agricultural } \\
\hline & D & A & $\mathbf{F}$ & C & D & A & $\mathbf{F}$ & C & D & A & $\mathbf{F}$ & C \\
\hline A. fraterculus* & $\mathrm{sd}$ & sa & $\mathrm{sf}$ & $\mathrm{w}$ & $\mathrm{sd}$ & sa & sf & $\mathrm{w}$ & $\mathrm{sd}$ & sa & sf & $\mathrm{w}$ \\
\hline A. bistrigata* & $\mathrm{sd}$ & sa & $\mathrm{sf}$ & $\mathrm{W}$ & $\mathrm{sd}$ & sa & sf & $\mathrm{w}$ & - & - & - & - \\
\hline A. sororcula* & $\mathrm{d}$ & va & vf & $\mathrm{w}$ & $\mathrm{sd}$ & sa & sf & $\mathrm{w}$ & $\mathrm{sd}$ & sa & sf & $\mathrm{w}$ \\
\hline A. obliqua* & sd & sa & sf & $\mathrm{w}$ & $\mathrm{sd}$ & sa & sf & $\mathrm{w}$ & nd & $\mathrm{c}$ & $\mathrm{f}$ & $\mathrm{y}$ \\
\hline A. bahiensis Lima, 1937 & - & - & - & - & $\mathrm{d}$ & va & $\mathrm{vf}$ & $\mathrm{w}$ & - & - & - & - \\
\hline A. grandis (Macquart, 1846) & $\mathrm{d}$ & $\mathrm{c}$ & $\mathrm{f}$ & $\mathrm{w}$ & d & va & $\mathrm{vf}$ & $\mathrm{w}$ & - & - & - & - \\
\hline A. pseudoparallela* & $\mathrm{sd}$ & sa & sf & $\mathrm{w}$ & d & $\mathrm{c}$ & $\mathrm{f}$ & $\mathrm{w}$ & nd & $\mathrm{c}$ & $\mathrm{f}$ & $\mathrm{y}$ \\
\hline A. distincta Greene, 1934 & nd & $\mathrm{c}$ & $\mathrm{f}$ & $\mathrm{z}$ & d & $\mathrm{c}$ & $\mathrm{f}$ & $\mathrm{y}$ & - & - & - & - \\
\hline A. serpentina (Wiedemann, 1830) & $\mathrm{d}$ & va & $\mathrm{vf}$ & $\mathrm{y}$ & nd & $\mathrm{c}$ & $\mathrm{f}$ & $\mathrm{y}$ & - & - & - & - \\
\hline A. pickeli & nd & $\mathrm{d}$ & lf & $\mathrm{z}$ & nd & $\mathrm{c}$ & $\mathrm{f}$ & $\mathrm{y}$ & nd & $\mathrm{c}$ & $\mathrm{f}$ & $\mathrm{y}$ \\
\hline A. barbiellinii Lima, 1938 & $\mathrm{~d}$ & va & $\mathrm{vf}$ & $\mathrm{y}$ & nd & $\mathrm{c}$ & $\mathrm{f}$ & z & - & - & - & - \\
\hline A. zenildae & nd & $\mathrm{r}$ & lf & $\mathrm{z}$ & nd & $\mathrm{d}$ & If & $\mathrm{z}$ & $\mathrm{d}$ & va & $\mathrm{vf}$ & $\mathrm{y}$ \\
\hline A. turpiniae Stone, 1942 & - & - & - & - & nd & d & If & $\mathrm{z}$ & sd & $\mathrm{sa}$ & sf & $\mathrm{y}$ \\
\hline A. amita Zucchi, 1979 & $\mathrm{~d}$ & $\mathrm{c}$ & $\mathrm{f}$ & $\mathrm{w}$ & nd & $\mathrm{r}$ & If & z & - & - & - & - \\
\hline A. leptozona Hendel, 1914 & nd & $\mathrm{r}$ & lf & $\mathrm{z}$ & nd & $\mathrm{r}$ & If & $\mathrm{z}$ & - & - & - & - \\
\hline A. punctata Hendel, 1914 & - & - & - & - & nd & $\mathrm{r}$ & If & $\mathrm{z}$ & - & - & - & - \\
\hline A. consobrina (Loew, 1873) & - & - & - & - & nd & $\mathrm{r}$ & If & $\mathrm{z}$ & - & - & - & - \\
\hline A. montei Lima, 1934 & nd & $\mathrm{d}$ & lf & $\mathrm{z}$ & nd & $\mathrm{r}$ & If & $\mathrm{z}$ & - & - & - & - \\
\hline A. striata Schiner, 1868 & - & - & - & - & - & - & - & - & nd & $\mathrm{c}$ & $\mathrm{f}$ & $\mathrm{y}$ \\
\hline A. manihoti Lima, 1934 & nd & $\mathrm{r}$ & lf & $\mathrm{z}$ & - & - & - & - & - & - & - & - \\
\hline A. daciformis Bezzi, 1909 & nd & $\mathrm{d}$ & lf & $\mathrm{z}$ & - & - & - & - & - & - & - & - \\
\hline A. dissimilis Stone, 1942 & nd & $\mathrm{c}$ & $\mathrm{f}$ & $\mathrm{z}$ & - & - & - & - & - & - & - & - \\
\hline Total & \multicolumn{4}{|c|}{12.201} & \multicolumn{4}{|c|}{26,296} & \multicolumn{4}{|c|}{11,086} \\
\hline Number of species (S) & \multicolumn{4}{|c|}{17} & \multicolumn{4}{|c|}{18} & \multicolumn{4}{|c|}{08} \\
\hline
\end{tabular}

$\mathrm{D}=$ Dominance $-\mathrm{sd}$ : superdominant, d: dominant, nd: not dominant; $\mathrm{A}=$ Abundance - sa: superabundant, va: very abundant, c: common, $\mathrm{d}$ : disperses, $\mathrm{r}$ : rare; $\mathrm{F}=$ Frequency - sf: super-frequent, vf: very frequent, f: frequent, lf: little frequent; $\mathrm{C}=$ constancy $-\mathrm{w}$ : constant, $\mathrm{y}$ : ancillary, z: accidental; *prevalent species.

FIGURE 1: Rarefaction curve for Anastrepha species in three different environment in the state of São Paulo, Brazil. (A: urban area; B: research station; C: agricultural area).

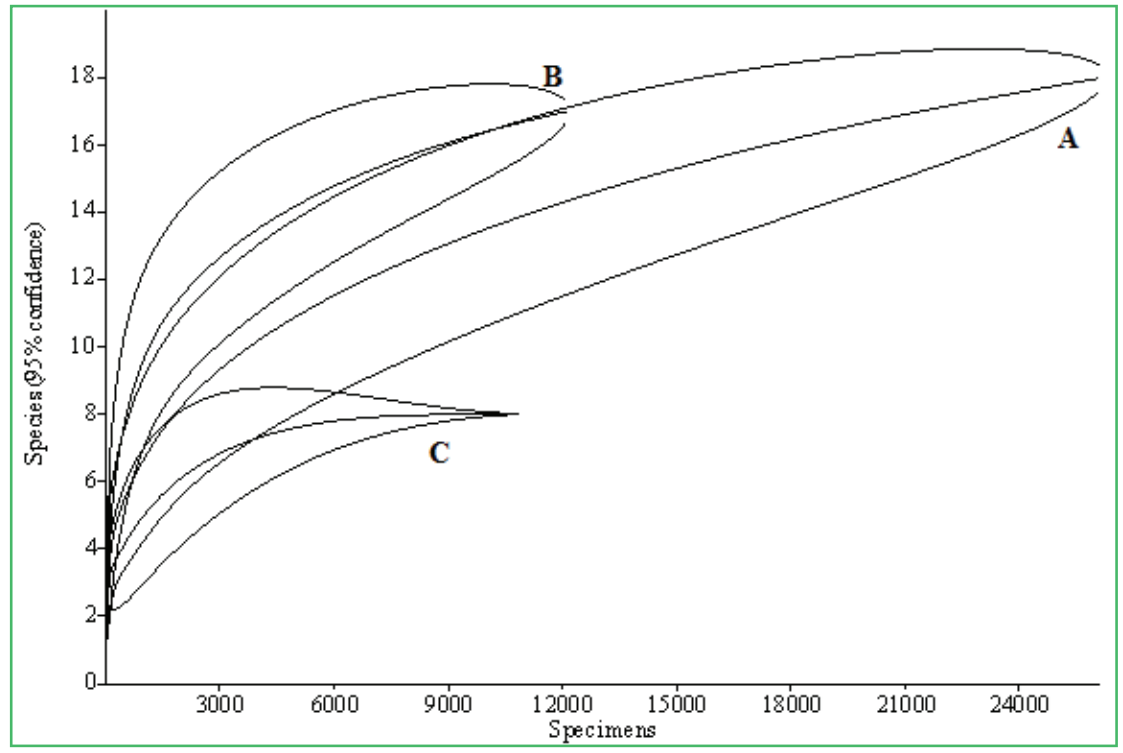


FIGURE 2: Q-statistic of Anastrepha species in three different environments in São Paulo, Brazil. Dashed line: lower quartile; filled line: upper quartile; gray line: Q-slope (interquartile). Species in the lower quartile are classified as singletons. (A: urban area; B: research station; C: agricultural area).

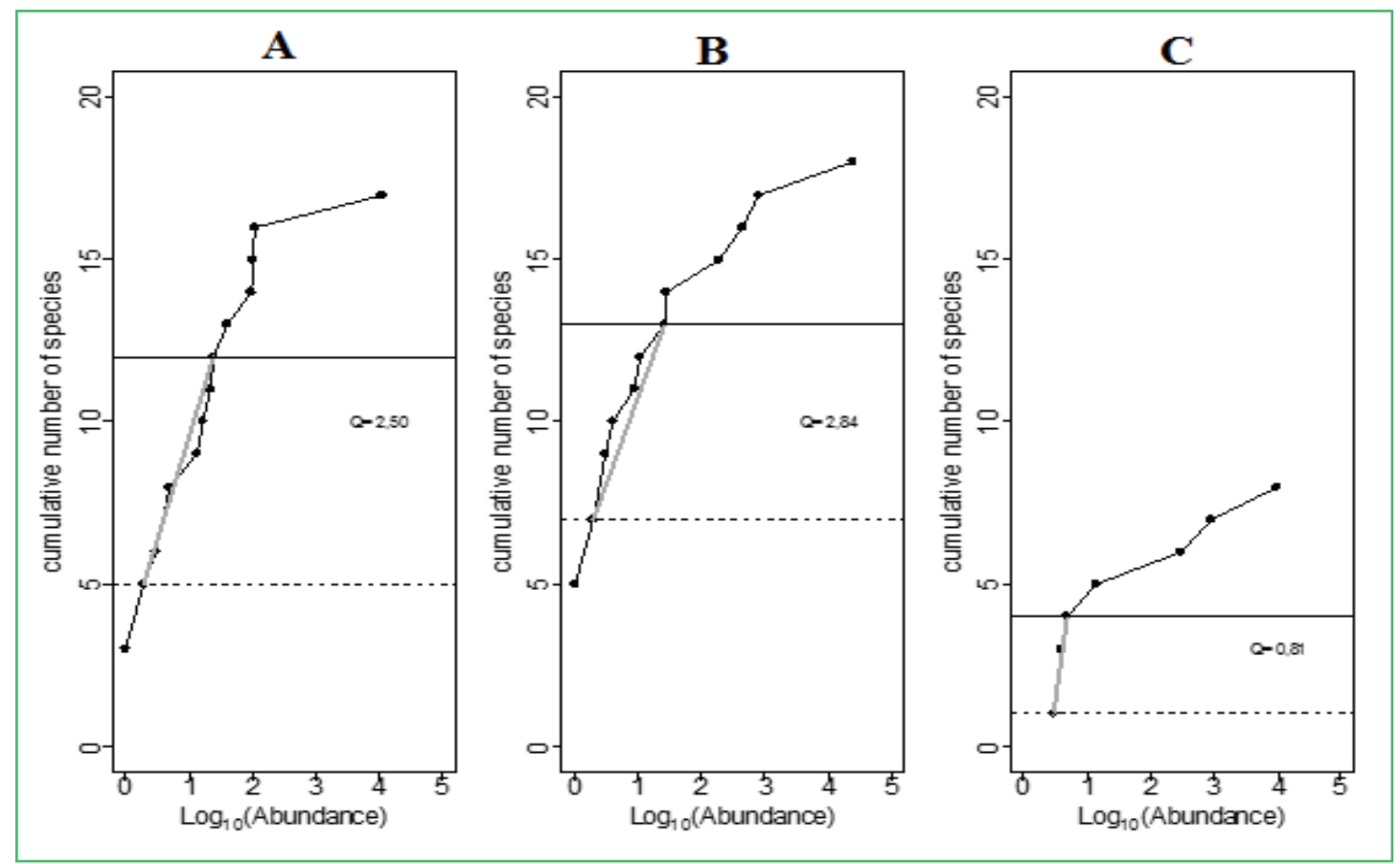

TABLE 2: Number of species $(\mathrm{S})$, abundance $(\mathrm{A})$, Shannon $\left(H^{\prime}\right)$, Margalef $\left(\mathrm{D}_{M g}\right)$, Pielou $\left(J^{\prime}\right)$ and Berger-Parker $(\mathrm{d})$ indices in three different environments in the state of São Paulo, Brazil.

\begin{tabular}{lccc}
\hline \multirow{2}{*}{ Index } & \multicolumn{3}{c}{ Area } \\
\cline { 2 - 4 } & Urban & Research station & Agricultural \\
\hline $\mathrm{S}$ & 17 & 18 & 8 \\
$\mathrm{~A}$ & 12,201 & 26,296 & 11,096 \\
$\mathrm{H}$ & $2,003 \pm 0.02 \mathrm{a}$ & $1,965 \pm 0.04 \mathrm{a}$ & $1,422 \pm 0.08 \mathrm{~b}$ \\
$\mathrm{D}_{\mathrm{Mg}}$ & 2.4 & 2.9 & 1.2 \\
$\mathrm{~J}$ & 0.78 & 0.74 & 0.88 \\
$\mathrm{~d}$ & 0.89 & 0.94 & 0.89 \\
Expected richness $( \pm)^{* *}$ & $17.64 \pm 3.87$ & $16.57 \pm 2.69$ & $7.98 \pm 0.56$ \\
\hline
\end{tabular}

*Means in the same column followed by the same letter are not significantly different at $(p>0.05)$; **Expected richness estimated by Chao 2 method, $\mathrm{CI}=$ confidence interval.

The Sørensen, index indicated that the urban area and research station were more similar, sharing 14 species. The agricultural area had lower similarity with other areas, mainly with the urban area (48\%), with which only 6 species were shared (Figure 3.1; Table 3). Anastrepha dissimilis and $A$. daciformis occured only in the urban area, $A$. bahiensis only in the research station, and $A$. striata only in the agricultural area (Table 1). Abundancebased similarity varied among areas, and the Bray-Curtis coefficient indicated higher similarity between agricultural and urban areas (Figures 3.1; 3.2). Anastrepha fraterculus had strong and nearly equivalent interactions with and associations for all three areas (Figure 4). 
TABLE 3: Similarity (based on the Sørensen index) of Anastrepha species captured in McPhail-type traps in three different environments in the state of São Paulo, Brazil.

\begin{tabular}{|c|c|c|c|c|c|}
\hline $\begin{array}{l}\text { Association of Treatments } \\
\text { (S1) }\end{array}$ & $\begin{array}{l}\text { Common } \\
\text { species (n) }\end{array}$ & $\begin{array}{l}\text { Species } \\
\text { (S1) }\end{array}$ & $\begin{array}{l}\text { Species } \\
\text { (S2) }\end{array}$ & $\begin{array}{c}\text { Sorensen* } \\
\text { Q (\%) }\end{array}$ & $\pm(\mathbf{C I})$ \\
\hline Urban x Research station & 14 & 17 & 18 & $80 a$ & 7.36 \\
\hline Urban x Agricultural & 06 & 17 & 08 & $48 b$ & 8.16 \\
\hline Research station x Agricultural & 07 & 18 & 08 & $53.85 \mathrm{~b}$ & 8.27 \\
\hline
\end{tabular}

*Similarity coefficient means followed by the same letter are not significantly different at $(p>0.05)$. CI $=$ Confidence interval.

FIGURE 3: Similarity dendrogram of Anastrepha species composition for all three areas. 1. Sørensen (In. Corr. $=0.985)$. 2. Bray-Curtis (In. Corr. $=0.995)$. (A: urban area; B: research station; C: agricultural area).

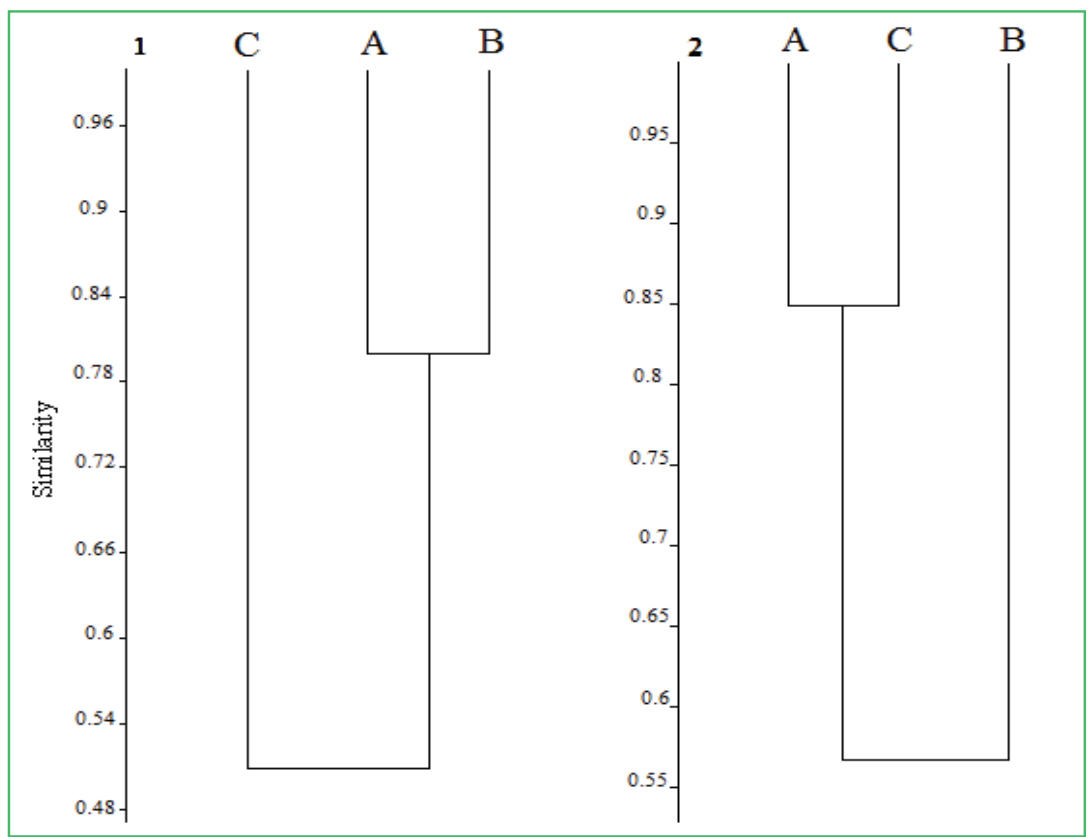

FIGURE 4: Interaction of Anastrepha species in three different environments in the state of São Paulo, Brazil (green: weak interaction; red: strong interaction) (A: urban area; B: research station; C: agricultural area).

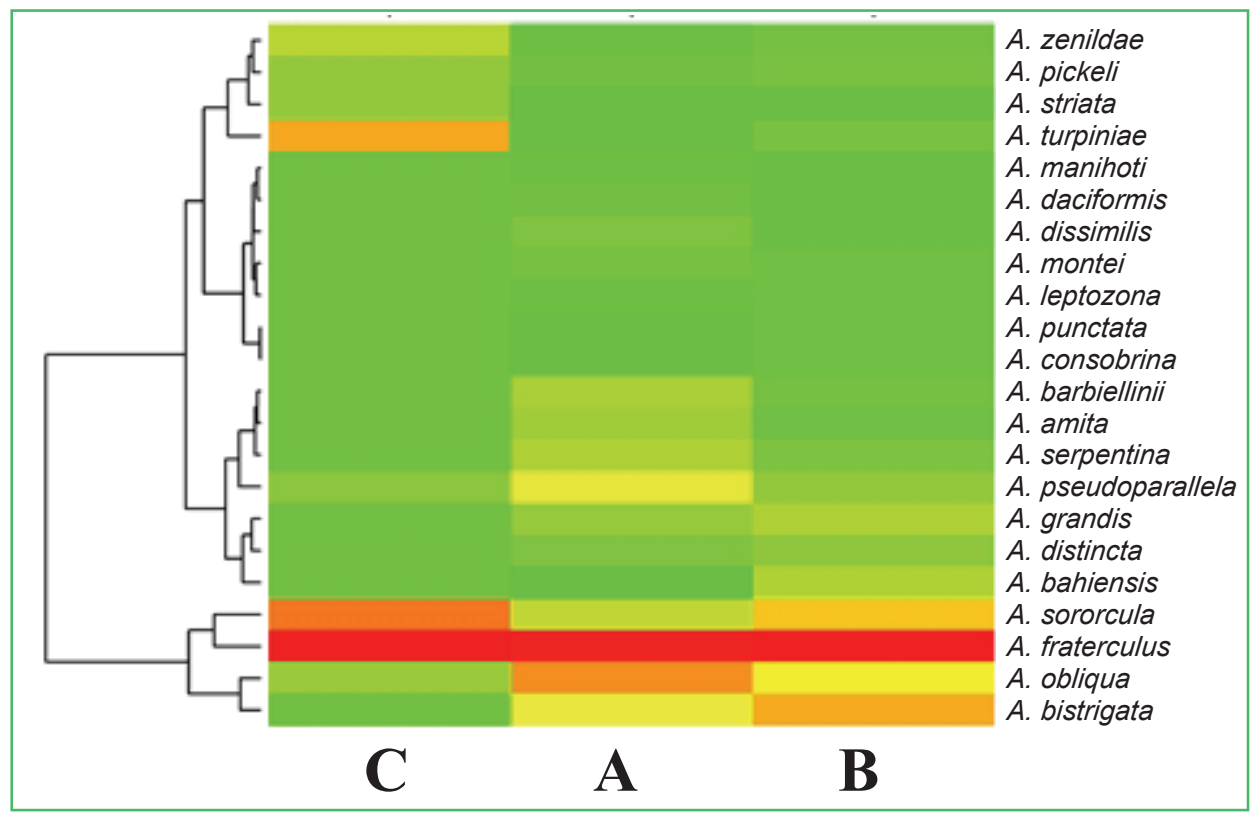




\section{Discussion}

Stabilization of the rarefaction curve (asymptote) was achieved more quickly in the agricultural area because $A$. fraterculus was super dominant and there was lower species richness. Approximately $50 \%$ of the Anastrepha species previously recorded for the state were captured in this study. Anastrepha fraterculus was common in all areas, and had the highest values for the indices included in the faunal analysis. Both species richness and the degree of evenness in species abundances seem to vary among assemblages. In some cases one or two species are dominant, with the remainder being infrequent or rare (MAGURRAN, 2004). The dominance of $A$. fraterculus can be explained by the ability of this species to develop on more than 100 different hosts (ZUCCHI, 2000), as host succession contributes to high abundance. Further, this species is polyphagous and strongly interacts with the areas, displacing other species (Figure 4). However, $A$. fraterculus is being considered herein in a broad sense, as this nomination refers to a complex of cryptic species. Other Anastrepha species were also common in all three areas, with emphasis on A. sororcula, A. obliqua and $A$. bistrigata.

Earlier studies have not considered the abundance distribution pattern of Anastrepha species, however, this knowledge is relevant for our understanding of colonization and exploitation strategies by fruit flies, as well as how anthropogenic disturbance influences distribution patterns (MAGURRAN, 2004). High values of equitability and dominance in all three areas are due to high abundance of $A$. fraterculus, and consequently, higher homogeneity among species. In the research station and urban area, the diversity, richness, and abundance of species can be attributed to the diversity of host plants in adjacent areas, and the absence of phytosanitary treatments. High diversity of fruit trees leads to greater Anastrepha species richness (ALUJA et al., 1996). The type of management adopted also significantly influences species richness and abundance.

The research station is essentially an abandoned orchard, with no phytosanitary treatment and without the removal of fruits from trees and soil. These conditions have contributed to the maintenance of a high abundance of Anastrepha species. In the urban area, despite the low abundance of fruiting trees, plant hosts were more diverse and fruited in different periods, ensuring resource availability throughout the year. Host availability is one of the main factors influencing fruit fly population dynamics (ALUJA, 1994); host succession also favors the occurrence of more species, as more fruits are available throughout year (PUZZI; ORLANDO, 1965). The availability of primary and secondary hosts is generally considered more important than the climate variations for determination of the abundance and diversity of Anastrepha species. Areas with high floristic diversity, or those that are less intensely managed, foster higher species diversity due to provisioning of sufficient quantities of the required resources for completion of the biological cycle. Environmental heterogeneity is also a relevant factor in studies of fruit fly community structure, because species diversity is correlated with spatial variation, a metric of habitat complexity (HATLEY; MACMAHON, 1980).

Few species were collected in the agricultural area, and relative frequency and diversity (Q) were lower. These types of areas generally contain dominant species with large populations, as observed for $A$. fraterculus, while other species have lower rates of population growth. The low abundance of Anastrepha species in this area was likely due to management practices in the orchard (phytosanitary treatments, harvesting of fruits, and plant runings). The lower richness in the agriculture area was probably due to higher landscape homogeneity and lower habitat complexity, being formed only by a guava orchard. As verified by the highest value of equitability index, demonstrated high abundance of a unique species (A. fraterculus) as is expected for agricultural systems (ALUJA et al., 1996).

In sustainably managed environments, monophagous species tend to have higher abundances, while polyphagous species tend to dominate in agricultural environments with intensive management, usually with dominance by one or two species (e.g., as observed in the current study with $A$. fraterculus) (ALUJA et 
al., 1996; MAGURRAN, 2004). Habitat modification and consequent loss of native vegetation affects monophagous species more intensely than polyphagous species. Environments with high degree of disturbance may result in intimate adaptation of species to their hosts. In agroecosystems, the intensity of fruit fly infestation is typically limited (ALUJA et al., 2012). The uniformity of the agricultural area in the current study (extensive area with only guava) contributed to the dissimilarity of this area with the other two areas. Species composition among areas may also vary depending on vegetation characteristics in adjacent areas. The similarity between the research station and the urban areas probably occurred due to having an abundance of fruits. Urban areas are primarily responsible for the maintenance of fruit fly species, a result of the deforestation and availability of domestic hosts. Forest fragments in urban area maintain the populations of Anastrepha species, similarly to the research station. The absence of rare species in the agricultural area indicates less diversity of hosts around the orchard, while the dissimilarity with the research station in terms of abundance is associated with the abandonment of this area, and high abundance of $A$. fraterculus.

Despite utilization of different management techniques and various level of anthropogenic influence among the study areas, fruit fly communities had similar abundance distribution patterns in all three areas, in which only a few species, mainly $A$. fraterculus, were dominant. However, Anastrepha species composition differed among in the three study areas, likely as a consequence of host species occurrence, abundance, and persistence over time.

\section{Acknowledgements}

We thankCAPES (Coordenação deAperfeiçoamento de Pessoal de Nível Superior) for providing a scholarship to the first author. MFSF and RAZ are felows of the Conselho Nacional de Desenvolvimento Científico e Tecnológico (CNPq).

\section{References}

ALUJA, M. Bionomics and management of Anastrepha. Annual Review of Entomology, Palo Alto, v. 39, p. 155-178, 1994.

ALUJA, M.; CELEDONIO-HURTADO, H.; LIEDO, P.; CABRERA, M.; CASTILLO, F.; GUILLÉN, J.; RIOS, E. Seasonal population fluctuations and ecological implications for management of Anastrepha fruit flies (Diptera: Tephritidae) in commercial mango orchards in Southern Mexico. Journal of Economic Entomology, Riverside, v. 89, p. 654-667, 1996.

ALUJA, M.; ORDANO, M.; GUILLÉN, L.; RULL, J. Understanding long-term fruit fly (Diptera: Tephritidae) population dynamics: Implications for areawide management. Journal of Economic Entomology, Riverside, v. 105, p. 823-836, 2012.

BERRYMAN, A. A. Forest insects: principles and practice of population management. New York: Plenum Press, 1986. 279 p.

CELEDONIO-HURTADO, H. M.; ALUJA, M.; LIEDO, P. Adult population of Anastrepha species (Diptera: Tephritidae) in tropical orchad habitats of Chiapas, Mexico. Environmental Entomology, Lanham, v. 24, p. 861-869, 1995.

GOTELLI, N. J. Ecologia. Vol. 4. Londrina: Editora Planta, 2009. $28 \mathrm{p}$.

HAMMER, O.; HARPER, D. A. T.; RIAN, P. D. Past: palaeontological statistics ver 1.37. 2007. Available at $<$ http://folk. uio.no/ohammer/past $>$. Accessed on: August 20, 2015.

HATLEY, C. L.; MACMAHON, J. Spider community organization: seasonal variational and role of vegetation architeture. Environmental Entomology, Lanham, v. 9, p. 632-639, 1980.

LEMOS, L. J. U.; SOUZA-FILHO, M. F.; URAMOTO, K.; LOPESMIELEZRSKI, G. N.; ZUCCHI, R. A. Espécies de Anastrepha (Diptera: Tephritidae) em pomares de goiaba: diversidade, flutuação populacional e fenologia do hospedeiro. Arquivos do Instituto Biológico, São Paulo, v. 82, p. 1-5, 2015.

LOPES, G. N.; SOUZA FILHO, M. F.; GOTELLI, N. J.; LEMOS, L. J. U.; GODOY, W. A. C.; ZUCCHI, R. A. Temporal Overlap and co-occurrence in a guild of sub-tropical tephritid fruit flies. Plos One, Cambridge, v. 10, p. e0132124, 2015.

MAGURRAN, A. E. Measuring biological diversity. Malden: Blackwell Publishing, 2004. 256 p.

NORRBOM, A. L.; KORYTKOWSKII, C. A.; ZUCCHI, R. A.; URAMOTO, K.; VENABLE, G. L.; McCORMICK, J.; DALLWITZ, M. J. Anastrepha and Toxotrypana: descriptions, illustrations, and interactive keys. 2012. Available at: $<\mathrm{http} / / /$ deltaintkey.com/anatox/intro.htm>. Accessed on: March 30, 2017.

PUZZI, D.; ORLANDO, A. Estudos sobre a ecologia de moscasdas-frutas (Trypetidae) no Estado de São Paulo, visando o controle racional da praga. Arquivos do Instituto Biológico, São Paulo, v. 32, p. 9-22, 1965.

R CORE TEAM. A language and environment for statistical computing. R 3.0.1, 2013. R Foundation for Statistical Computing. Available at: $<$ http://www.R-project.org>. Accessed on: May 15, 2015.

SILVEIRA NETO, S.; HADDAD, M. de L.; MORAES, R. C. B. de. Artropodofauna aérea. In: BENGER, G. U.; FAVORETTO, L. R. G. (Org.). Monitoramento ambiental soja Roundup Ready®. Botucatu: FEPAF, 2014. p. 727-769. 
SILVEIRA NETO, S.; NAKANO, O.; BARBIN, D.; NOVA, N. A. V. Manual de ecologia dos insetos. Piracicaba: Agronômica Ceres, 1976. 419 p.

URAMOTO, K.; WALDER, J. M. M.; ZUCCHI, R. A. Flutuação populacional de moscas-das-frutas do gênero Anastrepha Schiner, 1868 (Diptera, Tephritidae) no campus "Luiz de Queiroz", Piracicaba, São Paulo. Arquivos do Instituto Biológico, São Paulo, v. 70, p. 459-465, 2003.
ZUCCHI, R. A. Taxonomia. In: MALAVASI, A.; ZUCCHI, R. A. (Ed.). Moscas-das-frutas de importância econômica no Brasil: conhecimento básico e aplicado. Ribeirão Preto: Holos Editora, 2000. p. 13-24.

ZUCCHI, R. A. Fruit flies in Brazil - Anastrepha species their host plants and parasitoids. 2008. Available at $<$ www.lea.esalq.usp. br/anastrepha/>. Accessed on: March 30, 2017. 